This PDF is a selection from a published volume from the National Bureau of Economic Research

Volume Title: Measuring Capital in the New Economy

Volume Author/Editor: Carol Corrado, John Haltiwanger and Dan Sichel, editors

Volume Publisher: University of Chicago Press

Volume ISBN: 0-226-11612-3

Volume URL: http://www.nber.org/books/corr05-1

Conference Date: April 26-27, 2002

Publication Date: August 2005

Title: Measuring Organizational Capital in the New Economy

Author: Sandra E. Black, Lisa M. Lynch

URL: http://www.nber.org/chapters/c10622

Chapter pages in book: (205 - 236) 


\title{
Measuring Organizational \\ Capital in the New Economy
}

\author{
Sandra E. Black and Lisa M. Lynch
}

\subsection{What Is Organizational Capital?}

A growing body of literature over the past decade suggests that a firm's organizational structure or capital can contribute in significant ways to the productive capacity of a firm. But, as with other intangible assets, there is no consensus definition of what this organizational capital is, how to measure it, or how best to quantify its contribution to output (either current or future). Unlike physical capital, its value does not appear on the balance sheet of a firm, and when firms undertake substantial organizational change or reengineering this is typically treated as "consumption" rather than an increase in the assets of a firm. There is no "market" for organizational capital that we could use to generate a book value for it, and, unlike general human capital, it is not portable.

When considering the issue of measuring intangibles, a recent Brookings Task Force chaired by Margaret Blair and Steven Wallman (2001) suggested that there are three categories of intangible assets, each with more measurement problems than the next - the easiest category exists for assets

Sandra E. Black is assistant professor of economics at the University of California, Los Angeles (UCLA), and a faculty research fellow of the National Bureau of Economic Research. Lisa M. Lynch is the William L. Clayton Professor of International Economic Affairs at the Fletcher School of Law and Diplomacy, Tufts University, and a research associate of the $\mathrm{Na}$ tional Bureau of Economic Research.

This research was supported in part by the National Science Foundation Program on Innovation and Organizational Change. The research in this paper was conducted while the authors were Census Bureau Associates at the UCLA and Boston Research Data Centers. Research results and conclusions are those of the authors and do not necessarily indicate concurrence by the Bureau of the Census. This paper has been screened to ensure that no confidential data are revealed. The authors would like to thank Kathryn Shaw for her informative comments on an earlier draft of this chapter. 
that can be owned and sold, the next category is for those assets that can be controlled by the firm but not separated out and sold, and finally, the category with the most difficult measurement issues contains assets that may not be wholly controlled by the firm. Intangible assets such as copyrights, brand, and trade names would be in the first category, the relatively easily addressed category of measurement problems, since they can be bought and sold. However, the degree of control the firm has over assets such as the design of production processes, human capital, relationship capital, and organizational capital varies along with the ability of the firm to "sell" these assets. As a result, they are much more difficult to measure in the usual accounting sense.

Before we can discuss how to improve the measurement of organizational capital, we must first establish a working, albeit crude, definition of organizational capital. ${ }^{1}$ To do this we have chosen to focus on some of the elements of organizational capital that have been shown, in both theoretical and empirical studies, to be associated with higher productivity for firms and/or higher wages for workers. This is not meant to be an exhaustive list of all the elements of organizational capital but rather a starting point that is representative and tractable.

We divide organizational capital into three broad components-workforce training, employee voice, and work design (including the use of crossfunctional production processes). While we will discuss these categories separately, it is important to note that there are important links and synergies between each of these categories that contribute to the overall value of organizational capital within a firm.

Although training is usually thought of in the context of human capital, employer-provided training is an important component of workplace organization and organizational capital. We assume, for the sake of simplicity, that education decisions are primarily individual based and made independently from the employment relationship. But workplace training is a joint decision undertaken by the worker and the firm to invest in additional skills training after an employment relationship has begun. This workforce training, along with the education a worker brings to a job, raises the productive capacity of a firm. Training demands of a firm are not limited to the introduction of new technology; as new organizational structures such as teamwork are put in place, this increases the need of workers to acquire additional training to help them function in a more interactive group environment. At the same time, organizational capital may interact

1. For a different approach to and definition of organization capital see Atkeson and Kehoe (2002). They conclude that nearly half of the output in manufacturing that is not accounted for by payments to labor and capital could be attributed to organization capital. They also conclude that the value of this organization capital is roughly two-thirds the value of physical capital. They model the acquisition of organization capital as coming from endogenous learning-by-doing so it is embodied in the firm and jointly produced with measured output. But their empirical treatment of organization capital is based on plant-specific productivity and age rather than any actual workplace practices. 
with human capital, and the ability of a firm to undertake organizational change may be a function of the human capital of its workforce. Finally, spillover effects even for "specific training" may be much larger depending on the organizational structure of a firm in which these investments in human capital are made. For all of these reasons, then, we include workforce training under our umbrella of organizational capital.

The second component of organizational capital is employee voice. By this we mean those organizational structures that give workers, especially nonmanagerial workers, input into the decision making associated with the design of the production process and greater autonomy and discretion in the structure of their work. Traditional forms of work organization are very task specific; each production worker has a specific task to complete, and once they learn how to accomplish the task, there is little independent thought involved. However, newer forms of organization involve giving employees, specifically lower-level production workers, more input into the production process and greater opportunities to improve efficiency. As employee voice increases, firms are better able to tap into the knowledge of nonmanagerial workers.

There is a large continuum of practices associated with employee voice. These range from the employee suggestion box in the lunch room, to employees' being consulted individually about their views, to individual jobenrichment schemes, to employees' being consulted in groups, and finally to self-managed teams where production employees work in a semiautonomous setting. In addition, all of this can take place in the context of unionization, which may serve to help or hinder this communication process. As discussed by Malcomson (1983), agreements made between managers and workers may not be legally enforceable, so the presence of unions can address incentive compatibility problems that may arise at the workplace. In addition, negotiations that management undertakes with workers about the introduction of new workplace practices are less expensive if the company has to deal only with union specialists rather than each individual worker.

Our third component of organizational capital is work design, including the use of cross-functional production processes that result in more flexible allocation and reallocation of labor in the firm. Examples of practices in this component include reengineering efforts that may involve changing the occupational structure of the workplace (including increasing the number of technical workers), the number of workers per supervisor, the number of levels of management within the firm, the existence and diffusion of job rotation, and job share arrangements. We also include in this component methods by which firms monitor their practices relative to others, such as benchmarking. Some of the changes we see in work design are associated with the introduction and diffusion of information technologies within the firm. For example, as new technologies reduce the cost of lateral communication, we see firms using these technologies to facilitate greater 
communication between and across workers, both managerial and nonmanagerial. Monitoring technologies can also be used to reduce the number of supervisors required in the production process. So there are possible complementarities between this and other dimensions of organizational capital, as well as with investments in physical capital.

While it is not a type of organizational capital per se, incentive-based compensation plays an important role in organizational capital. More generally, if we observe wage premiums being paid in employment situations where there is a higher level of organizational capital we might, in a very crude way, think of this premium as another way to "price" the value of the asset we are calling organizational capital. Employers will use wages and other forms of compensation to try to hold on to this relational asset. In addition to the basic wage, employers can also pay workers by piece rate, stock options, profit sharing, and bonuses related to achieving specific production targets. These are all tools that firms have used to, in part, realign workers' interests toward those of shareholders. But when workers are asked to come forward with ideas that would improve the production process but may also put their own jobs at risk, they must be given an incentive to do this.

Putting a portion of compensation "at risk," especially for nonmanagerial employees, can have an important effect on the amount and type of relationship capital that exists within a firm and can have a large effect on workers' discretionary effort. Recent work by Boning, Ichniowski, and Shaw (2001) has found strong evidence of complementarity between employee voice and incentive pay. So while incentive-based pay is not organizational capital per se, it is an important glue that holds the organizational capital together and keeps it within the firm. Therefore, in the remaining discussion on measurement issues we will also include this dimension of workplace practices.

Our three components are not an exhaustive list of possible elements of organizational capital. For example, Kruse and Blasi (1998) identify employment security and recruitment and selection systems as important components of what they label high-performance work practices. But as with compensation, employment security and recruitment and selection systems are probably best thought of as "glue" rather than organizational capital. The next section summarizes some of the empirical work on the impact organizational capital has had on firms and workers.

\subsection{The Importance of Organizational Capital in the New Economy: Empirical Evidence}

The importance of correctly measuring organizational capital stems from the evidence on its impact along a number of dimensions-labor productivity, wages, and labor demand. In addition, there is evidence of links 
between organizational capital, human capital, and physical capital, especially information and communication technologies.

In terms of productivity, there is an extensive literature documenting the relationship between organizational capital and firm performance. ${ }^{2}$ Examples of intra-industry studies include work by Ichniowski, Shaw, and Prennushi (1997), Arthur (1994), Kelley (1994, 1996), Bailey (1993), and Dunlop and Weil (1996). By examining human resource practices associated with one specific production process it is possible to greatly reduce problems of underlying heterogeneity of production processes. Most of the intra-industry studies conclude that the adoption of a coherent system of new human resource management practices such as flexible job definitions, cross-training, and work teams, along with extensive reliance on incentive pay, results in substantially higher levels of productivity than more traditional human resource management practices.

Another research strategy is to examine a more representative crosssectional sample of firms to determine the impact of workplace practices on broader measures of performance such as productivity or profitability. Examples of this strategy include Black and Lynch (2001, 2004), Bartel (1989), Bresnahan, Brynjolfsson, and Hitt (2002), Caroli and Van Reenen (2001), Ichniowski (1990), Huselid (1995), Huselid and Becker (1996), and Delaney and Huselid (1996). All of these studies have found a correlation between human resource management systems and business performance as measured by labor productivity, Tobin's $q$, or present-value gain in cash flow and firm market value. Many of these have also found evidence of the existence of synergies among workplace practices: the total impact is greater than the sum of the parts. ${ }^{3}$

Given that this volume is interested in measurement issues from the perspective of the economy as a whole, is it possible to translate some of the micro-based evidence on the impact of organizational capital on labor productivity to the economy more generally? In particular, since a large fraction of the output growth in manufacturing in the 1990s was driven by increases in multifactor productivity, can any of this be potentially attributed to organizational capital? In Black and Lynch (2004), we use our estimates of the impact of workplace practices on labor productivity in manufacturing (done using establishment-level data) in a growth-accounting framework in order to see, roughly, how much of the overall growth in manufacturing during 1993-95 our measures of workplace innovation could

2. See Ichniowski and Shaw (2003) for a thorough review of this literature.

3. The theoretical work of Milgrom and Roberts (1995) and Kandel and Lazear (1992), along with the empirical studies mentioned above, are important contributions in this area. Milgrom and Roberts argue that the impact of a system of human resource practices will be greater than the sum of its parts because of the synergistic effects of bundling practices together. Kandel and Lazear argue that introducing a profit-sharing plan for all workers in a firm may have little or no impact on productivity unless it is linked with other practices that address the inherent free-rider problem associated with corporatewide profit-sharing plans. 
Table 6.1

Compound average annual rates of growth in output and the contribution of factor inputs and multifactor productivity, manufacturing $(\%$ per year), 1993-96

\begin{tabular}{lcc}
\hline & $\begin{array}{c}\text { Bureau of } \\
\text { Labor Statistics }\end{array}$ & $\begin{array}{c}\text { Black and } \\
\text { Lynch (2004) }\end{array}$ \\
\hline Output & 4.2 & 4.7 \\
Combined inputs (includes capital, & 2.3 & 3.2 \\
$\quad$ labor, and materials) & 1.9 & 1.6 \\
Multifactor productivity & & 1.4 \\
$\quad$ Contribution of workplace practices & & 0.2 \\
$\quad$ Remaining residual & & \\
\hline
\end{tabular}

Sources: Bureau of Labor Statistics, Multifactor Productivity Trends, 1998, released September 21, 2000 and authors' own calculations from the EQW-NES first and second round cross sections with a 1 percent trim as presented in Black and Lynch (2004).

account for. We present these calculations again in table 6.1 along with the figures reported by the Bureau of Labor Statistics (BLS) over the same time period to "benchmark" our findings with their numbers. As seen in this table, the sample of manufacturing establishments that we used in our empirical work (the Educational Quality of the Workforce survey [EQW]) experienced very similar output growth over the period 1993-96 as reported by the BLS for the country as a whole. The BLS reports that output growth in manufacturing grew at a compound average annual growth rate of 4.2 percent between 1993 and 1996. We find a rate of 4.7 percent using the EQW data over the same period. The BLS reports that combined inputs (capital, labor, and materials) grew 2.3 percent over this period, and using the estimated coefficients from our empirical work (Black and Lynch 2004) as shares we find that inputs grew at 3.2 percent for the EQW sample. As a result, multifactor productivity grew 1.9 percent in the BLS reported figures and 1.6 percent using EQW data.

As a rough approximation of the contribution of organizational capital, we use the coefficients on the workplace practices that come from our microlevel production function estimation to calculate the impact of workplace innovation on multifactor productivity. We find that they contributed 1.4 percentage points per year. In other words, changes in organizational capital may have accounted for approximately 30 percent of output growth in manufacturing over the period 1993-96, or 89 percent of multifactor productivity. An important caveat is that many of the components of workplace organization, such as reengineering, reflect both technological as well as organizational changes. Though the number seems high, we believe that this accounting exercise indicates that measuring organizational capital can go some way in explaining recent trends in multifactor productivity.

Given that it improves productivity, it is not surprising to find that organizational capital also has an impact on workers, both in terms of their 
wages and in terms of skill demand. Investments in organizational capital seem likely to benefit the workforce because workers are unlikely to contribute in the manner these practices require unless they are assured a share of the gains (Osterman 2000). Organizational changes may also require a higher level of human capital from individual workers since they need to deal effectively with increased uncertainty and responsibility (see Osterman 1994 and Lynch and Black 1998). In terms of the empirical work on the impact of organizational capital on wages, the evidence is mixed. Using data from a representative sample of employers, Osterman (2000) finds no impact of work organization practices on wages of either core workers or all workers over the period 1996-97, and Cappelli and Carter (2000) find no impact on wages of nonmanufacturing workers. In contrast, both Black, Lynch, and Krivelyova (2004) and Cappelli and Neumark (2001) find that wages of manufacturing workers increase when employers extend their usage of organizational practices such as team work. Black, Lynch, and Krivelyova also find that the impact of organizational capital has the largest effect on the wages of supervisors, production, and sales or clerical workers in the manufacturing sector.

The March 2001 Industrial and Labor Relations Review is a special issue devoted to the impact of technology and work organization on wage inequality at the industry level. While not all studies in this volume were able to have access to data on organizational capital, some studies in this volume, such as Hunter and others (2001), Batt (2001), and Bailey, Berg, and Sandy (2001) find a significant relationship between workplace organizational practices and earnings.

While there has been less done on the impact of organizational capital on labor demand, several recent studies have looked at this question. Theoretically, as discussed by Kremer and Maskin (1996) and Acemoglu (2000) and reviewed in the context of organizational change and wage inequality by Aghion, Caroli, and Garcia-Peñolosa (1999), when technological and organizational change takes place, skill homogeneity can increase within firms. Therefore, if technical change and organizational change are complementary activities, as argued in Bresnahan, Brynjolfsson, and Hitt (2002), and since technical progress tends to be skill biased, it may be the case that the organizational change would also be skill biased. Osterman (2000) finds that measures of organizational capital are associated with a higher probability of layoffs, even within firms that have been experiencing net gains in total employment. This is suggestive of the reallocation process hypothesized in Kremer and Maskin and Acemoglu. Caroli and Van Reenen (2001) find evidence for British and French firms that a variety of measures, consistent with our definition of organizational capital, are associated with reduced demand for unskilled workers in both countries.

While the focus of this paper is not on measuring information technology, several researchers have found strong positive correlations between 
firms' decisions to adopt new technologies, especially information technology (IT), and additional investment in organizational capital. Bresnahan, Brynjolfsson, and Hitt (2002) find evidence of strong complementarity between several indicators of IT use, workplace organization, and the demand for skilled labor. The positive correlation between computers and workplace practices is also shown in Lynch and Black (1998) and Caroli and Van Reenen (2001). Finally, it is important to note that, while we have divided our measure of organizational capital into three components, there is an extensive literature, both theoretical and empirical, that suggests the existence of synergies in practices. For example, Athey and Stern (1998) discuss how the existence of complementarity in workplace practices implies that the adoption of one practice has externalities for adoption decisions about other practices. In addition, if practices are adopted in clusters, then some combinations of practices may occur only infrequently, making it difficult, empirically, to precisely estimate the impact of these practices on outcomes such as productivity.

\subsection{How Has Organizational Capital Been Measured?}

Data on organizational capital and related components such as compensation, recruitment and selection methods, and employment security provisions have been collected at three levels of aggregation. The first level of aggregation is case studies of individual companies. One of the most famous examples is the 1983 Harvard Business School case study of the Lincoln Electric Company by Norman Berg and Norman Fast; another, more recent example is Ann Bartel's (2004) study of a Canadian bank. The next level of aggregation includes detailed intra-industry studies such as the work by Ichniowski, Shaw, and Prennushi (1997) on the integrated steel industry. One of the many benefits of intra-industry data is the ability to examine organizational practices without the confounding effect of different production processes and organizational structure that are due to the production of different goods.

But the focus of this paper is to examine how more nationally representative surveys of businesses have attempted to capture these measures of organizational capital. This will help identify whether or not there are some measures of organizational capital that might be relatively easy to add to nationally representative ongoing surveys of businesses. This could be especially useful from a national incomes account perspective. For this purpose we focus on micro employer surveys from the 1990s that measure the components of organizational capital we believe have been shown to be the most important in analyses of productivity, wages, and labor demand.

One of the earliest surveys of workplace practices to use these measures to study their impact on labor productivity and Tobin's $q$ was Ichniowski (1990). He used data on personnel policies and practices taken from a 1986 
Table 6.2

Survey questions on training

\begin{tabular}{ll}
\hline Survey & \multicolumn{1}{c}{ Training questions asked } \\
\hline Ichniowski (1990) & $\begin{array}{l}\text { Does your business have a formal employee training and } \\
\text { development program? }\end{array}$ \\
$\begin{array}{l}\text { Huselid (1995), Huselid and } \\
\text { Becker (1996) }\end{array}$ & $\begin{array}{l}\text { How many hours of training per year are typically received by } \\
\text { an experienced employee (someone employed more than one } \\
\text { year)? }\end{array}$ \\
Osterman (1994, 2000) & $\begin{array}{l}\text { Proportion of core employees who received different types of } \\
\text { training (e.g., off the job or cross training) }\end{array}$ \\
Gittleman, Horrigan, and & $\begin{array}{l}\text { Variety of training incidence measures including types of } \\
\text { training offered (basic, workplace-related, and job skills) along }\end{array}$ \\
with reason for training (technology, skill specificity, seniority, \\
retention) \\
Black and Lynch (1996, 2001, 2004),
\end{tabular}

survey by Columbia University's Industrial Relations Research Center covering 495 Compustat II business lines. This was a mailed survey of the Compustat sample with a 10 percent response rate. Tables 6.2-6.4 summarize some of the questions used from this survey divided into the three components of organizational capital we are looking at - training, employee voice, and work design. The training measure is a simple incidence of formal training. The employee voice measure is primarily the right of workers to voice complaints under some form of due process rather than any type of direct employee participation in decision making within the firm. Finally, the measure of work design collapses a variety of different work structures into one variable. In the empirical work done with these measures, they are not introduced on their own but rather are collapsed into nine clusters of practices.

Mark Huselid conducted two mailed surveys of U.S. firms in 1992 and 1994. Surveys were mailed to 3,477 firms in 1992 and 3,847 firms in 1994, and employers were asked about their organizational practices in the previous year. The sample was drawn from the 12,000 publicly held firms listed in Compact Disclosure, a commercially available database containing annual 10-K reports. The overall response rate was 28 percent in 1992 and 20 percent in 1994. In addition, there was a subsample of firms that responded 
Table 6.3 Survey questions on employee voice

\begin{tabular}{|c|c|}
\hline Survey & Employee voice questions asked \\
\hline Ichniowski (1990) ${ }^{\mathrm{a}}$ & $\begin{array}{l}\text { Do you have any formal information sharing program with these } \\
\text { groups of employees? } \\
\text { Do you conduct attitude surveys among any of these groups of } \\
\text { workers? } \\
\text { Is there a formal grievance procedure or formal complaint resolution } \\
\text { system? }\end{array}$ \\
\hline $\begin{array}{l}\text { Huselid (1995), Huselid and } \\
\text { Becker (1996) }\end{array}$ & $\begin{array}{l}\text { What proportion of the workforce are included in a formal } \\
\text { information-sharing program (e.g., a newsletter)? } \\
\text { What proportion of the workforce is regularly administered attitude } \\
\text { surveys? } \\
\text { What proportion of the workforce participate in Quality of Work } \\
\text { Life (QWL), Quality Circles (QC), and/or labor management } \\
\text { participation programs? }\end{array}$ \\
\hline Osterman $(1994,2000)$ & $\begin{array}{l}\text { Proportion of the establishment's core employees involved in problem } \\
\text { solving groups } \\
\text { Proportion of the establishment's core employees involved in teams } \\
\text { Proportion of the establishment's core employees involved in Total } \\
\text { Quality Management (TQM) }\end{array}$ \\
\hline $\begin{array}{l}\text { Gittleman, Horrigan, and } \\
\text { Joyce (1998) }\end{array}$ & $\begin{array}{l}\text { Are there worker teams in the establishment? } \\
\text { Is there TQM? } \\
\text { Are there Quality Circles? } \\
\text { Is there employee involvement in the establishment's technology and } \\
\text { equipment purchase decisions? }\end{array}$ \\
\hline $\begin{array}{l}\text { Black and Lynch } \\
\quad(1996,2001,2004)\end{array}$ & $\begin{array}{l}\text { Is there TQM? } \\
\text { Proportion of non-managerial workers meeting regularly to discuss } \\
\text { workplace issues } \\
\text { Proportion of workers in self-managed teams }\end{array}$ \\
\hline Caroli and Van Reneen (2001) & $\begin{array}{l}\text { For any of the organizational methods I will mention (including } \\
\text { delayering, Just-in-Time, Quality Circles, and TQM) would you tell } \\
\text { me if it is already implemented, in the process of being so, being } \\
\text { considered, or not even thought of, in your establishment? }\end{array}$ \\
\hline
\end{tabular}

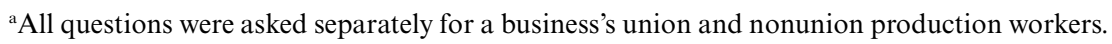

to both surveys, allowing for longitudinal analysis of organizational structure and performance outcomes of the firm. The survey included information on a wide range of organizational practices (shown in tables 6.2-6.4). The responses to these questions were then factor analyzed to see their impact on Tobin's $q$ and the gross rate of return on assets.

While Ichniowski and Huselid both focused their surveys on large business lines or entire firms, Paul Osterman employed a slightly different strategy and focused on individual establishments. He conducted two telephone surveys (rather than mail) in 1992 and 1997 to compile a nationally representative sample of U.S. establishments. By directing the questions to es- 


\begin{tabular}{|c|c|}
\hline Survey & Work design questions asked \\
\hline Ichniowski (1990) & $\begin{array}{l}\text { Does your organization use a formal job design program to integrate } \\
\text { work content and the qualifications required of employees to perform } \\
\text { work? If yes what type of job design do you use? (a) work } \\
\text { simplification, (b) job rotation, (c) job enlargement, (d) job enrichment, } \\
\text { or (e) other }\end{array}$ \\
\hline $\begin{array}{l}\text { Huselid (1995), Huselid } \\
\text { and Becker (1996) }\end{array}$ & $\begin{array}{l}\text { What proportion of the workforce hold jobs that have been included in } \\
\text { a formal job analysis? }\end{array}$ \\
\hline Osterman $(1994,2000)$ & Proportion of the core employees involved in job rotation \\
\hline $\begin{array}{l}\text { Gittleman, Horrigan, and } \\
\text { Joyce (1998) }\end{array}$ & Is there job rotation? \\
\hline $\begin{array}{l}\text { Black and Lynch } \\
\quad(1996,2001,2004)\end{array}$ & $\begin{array}{l}\text { Variety of measures including benchmarking, reengineering, number } \\
\text { of managerial levels, percentage of workers in job rotation, job sharing }\end{array}$ \\
\hline $\begin{array}{l}\text { Caroli and Van Reneen } \\
\text { (2001) }\end{array}$ & $\begin{array}{l}\text { Have you in the last three years made any substantial changes in work } \\
\text { organization or working practices not involving new plant machinery } \\
\text { or equipment that directly affected the jobs or working practices of } \\
\text { the manual workforce-and then asked for nonmanual workers? (for } \\
\text { British est.) } \\
\text { For any of the organizational methods I will mention, would you tell } \\
\text { me whether it is already implemented, in the process of being so, being } \\
\text { considered, or not even thought of in your establishment (included in } \\
\text { this list is delayering, quality circles, and TQM)? (French data) }\end{array}$ \\
\hline
\end{tabular}

tablishments rather than corporate headquarters, he hoped to obtain more accurate information about implementation of workplace practices. The response rates to the surveys were 65 percent for 1992 (806 establishments) and 58 percent for 1997 (683 establishments). The 1997 survey also contained a subsample of 462 establishments that were also interviewed in 1992, thereby allowing for longitudinal analysis. The questions on workplace practices were restricted, however, to "core" employees within the establishment and covered the proportion of these type of workers in training, self-managed work teams, job rotation, quality circles or off-line problem solving groups, and Total Quality Management (see tables 6.26.4 for more information on the types of questions asked).

The BLS Survey of Employer-Provided Training (SEPT) was conducted in 1993. While the primary purpose of this survey was to collect detailed information on employer training provided or financed by private nonagricultural establishments, information on other organizational practices was also collected. Nearly 12,000 establishments were surveyed, with a response rate of 71.3 percent (7,895 establishments). In addition to answering extensive questions on types of training and training practices, 5,987 establishments provided information on the organization of work. The tar- 
get respondent was first the training department, next the human resource department, and finally the office manager. Establishments were asked which, if any, of the following six work organization practices were in existence in 1993: worker teams, total quality management, quality circles, peer review of employee performance, employee involvement in the firm's technology and in equipment purchase decisions, and job rotation. (See Gittleman, Horrigan, and Joyce 1998 for more details as well as tables 6.2-6.4.)

The data set we have used for our own work on labor productivity, training, and wages (e.g., Black and Lynch 1996, 2001, 2004; Black, Lynch, and Krivelyova 2004; and Lynch and Black 1998) comes from the EQW National Employers Survey conducted in 1994 and 1997. The EQW National Employers Survey (NES) was first administered by the U.S. Bureau of the Census as a telephone survey in August and September 1994 to a nationally representative sample of more than 3,000 private establishments with more than 20 employees. The survey represents a unique source of information on how employers recruit workers, organize work, invest in physical capital, and utilize education and training investments. The survey oversampled establishments in the manufacturing sector and establishments with more than 100 employees. Public-sector employees, not-forprofit institutions, and corporate headquarters were excluded from the sample. The target respondent in the manufacturing sector was the plant manager and in the nonmanufacturing sector was the local business site manager. However, the survey was designed to allow for multiple respondents, so that information could be obtained from establishments that kept financial information such as the book value of capital or the cost of goods and materials used in production at a separate finance office (typically at corporate headquarters for multi-establishment enterprises). Computerassisted telephone interviewing (CATI) was used to administer each survey, which took approximately twenty-eight minutes to complete.

The sampling frame for the survey was the Bureau of the Census Standard Statistical Establishment List (SSEL) file, one of the most comprehensive and up-to-date listings of establishments in the United States. By design, the survey allowed for a subset of establishments to be matched to the Census Longitudinal Research Database (LRD) that includes longitudinal information for manufacturing establishments only. The LRD, housed at the Center for Economic Studies at the Bureau of the Census, was created by longitudinally linking the establishment-level data from the Bureau of the Census's Annual Survey of Manufacturers (ASM). The LRD data include information on shipments, materials, inventories, employment, expenditures on equipment and structures, book values of equipment and structures, and energy use (for more information on the LRD see Haltiwanger and Davis 1991). Because we are able to match the LRD with the EQW NES, we have annual establishment-level data on inputs and outputs of production for the manufacturing employers in our 
survey. It is important to note that the LRD is basically the universe of all manufacturing establishments with more than 250 employees but is only a subsample of establishments with less than 250 employees.

The response rate for manufacturing establishments in the 1994 EQW NES was 66 percent (1,621 establishments) and 60.6 percent (1,324 establishments) for nonmanufacturing establishments. These response rates are substantially higher than most other voluntary establishment surveys. Probit analysis (available from the authors upon request) of the characteristics of nonrespondents indicates that there was no significant pattern at the two-digit industry level in the likelihood of participating in the survey. The only businesses more likely not to participate were manufacturing establishments with more than 1,000 employees.

The telephone survey was repeated again in 1997 and the overall response rate was 59 percent (4,139 establishments). There was also a subsample of 766 establishments that had been interviewed in 1994. The response rate of establishments in the longitudinal sample was 74 percent. In both surveys, a wide range of questions were asked about training and workplace practices. The training questions included not only incidence measures of whether the establishment undertook any formal training of its workers but also types of training (e.g., computer literacy, team work training, literacy training), the proportion of workers trained by five occupational categories, and the percentage of total labor costs that training expenditures represented. In terms of employee voice, the survey included questions about the proportion of nonmanagerial workers meeting regularly to discuss workplace issues, total quality management, the proportion of workers in self-managed teams, and union status. For work design, the surveys included questions about the usage of benchmarking, the percentage of workers in job rotation, the number of managerial layers, and whether the establishment had undergone any reengineering efforts.

The last surveys we examine are those British and French data sets used by Caroli and Van Reenen (2001) for their work on workplace organization and skill demand. The British data are from the British Workplace Industrial Relations Survey (WIRS), an establishment-level data set that consists of a cross section of over 2,000 British establishments in 1984 and 1990. In 1984 there are a number of questions that relate to organization change, and in 1990 there is a limited follow-up that asks more basic information. In both surveys, senior managers are asked whether there has been an introduction of new plant, machinery, or equipment that includes new microelectronic technology; the introduction of new plant, machinery, or equipment not including new micro-electronic technologies; and whether there have been substantial changes in work organization or working practices not involving new plant, machinery, or equipment. A positive response to the last question would indicate changes in organizational capital. Caroli and Van Reenen attempted to verify that the change in organizational 
capital indicated in the survey actually corresponded to changes in relevant workplace practices by examining the 1984 data, in which managers were asked in more detail what the change actually involved. In general, this change in work organization was associated with increases in responsibility and is more likely to be associated with a widening range of more interesting tasks performed by workers.

The corresponding French data set is the REPONSE (Relations Professionnelles et Negociations d'Entreprise), which was constructed with reference to the British WIRS. They surveyed 2,500 establishments, asking senior managers in 1992 about industrial relations and organization in 1989-92. This survey includes more detailed information on workplace organization, including explicit questions on delayering (removing one or more managerial levels), quality circles, and total quality management. (See Caroli and Van Reenen 2001 for more details on both the British and the French surveys.)

It is clear that there is no one way that has been used to conduct these surveys. All of these surveys target different respondents, use a range of sampling frames, target different levels of the firm (from the establishment to business lines to the firm as a whole) for measures of organizational practices, utilize different methods to conduct the survey (mail or telephone), and have a range of response rates. The next section of the paper summarizes some of measurement problems that arise from this range of strategies to collect information on organizational capital.

\subsection{Measurement Issues}

There are a number of issues regarding data collection of organizational capital; however, many of these issues are not unique to organizational capital. One of the more basic questions is what is the appropriate business unit to study when considering organizational structure. Does each firm have a particular organizational structure, or is it even deeper than that, and does organizational structure vary within the firm across establishments? Interestingly, there has been little focus on this question, with a variety of studies using different units of observation. Bartel (1989) uses a data set in which the business line is the unit of observation, Huselid (1995) and Huselid and Becker (1996) use firm-level data, while Black and Lynch $(1996,2001,2004)$ use establishment-level data.

Once the appropriate unit of observation is determined, the next question becomes who should be surveyed. Responses obtained from workers within a firm might be different from those obtained from managers, which in turn may be different from responses from human resource workers. In the training literature, there is evidence that firms report that significantly more training is given by firms than is actually received by workers when workers are queried (see, e.g., Barron, Berger, and Black 1997, 1999). Gen- 
erally, the literature to date has focused on employer surveys under the assumption that employers have a better knowledge of the workplace structure and training that is being implemented. In addition, recent data collection efforts have focused on the human resource officer or training manager as the target respondent for questions pertaining to organizational structure. For smaller firms, this individual may be sufficiently knowledgeable to also answer questions on the financial aspect of the firm. However, with larger firms and perhaps more detailed surveys, as was the case in the EQW NES, there may be multiple target respondents, with the financial officer answering questions on investment and output and the human resource officer answering questions on organizational structure.

Other issues that make organizational capital hard to measure deal with its intangible nature. The ability to calculate the depreciation rate of intangible goods has long eluded economists. High turnover could cause organizational capital to depreciate very quickly, whereas strong firm attachment could slow depreciation.

When considering the best way to measure organizational capital, evidence suggests that incidence of activities is not sufficient. It is crucial to know not only whether practices were implemented but also how these practices are diffused both across employees or occupations and among employees within occupations. In addition, it is vital to know how long the practices have been in effect and what the start-up costs were: both direct, in terms of dollars spent by the firm, and indirect, in terms of worker time are found to affect wages, productivity, and skill demand. Finally, it is important to know how are these practices being used together.

While the previous section of this paper summarized overall response rates to surveys that asked questions about organizational practices, the overall response rates do not reveal variations in response rates to specific types of questions included in these surveys. Sometimes employers are confused by jargon that is unfamiliar to them or are concerned that answering a question may reveal proprietary information. Or employers may simply have a difficult time coming up with an accurate answer in the context of a short telephone or mailed survey. Therefore, it is important to understand which types of questions employers have an easier time responding to. In order to understand the efficacy of recent efforts to characterize workplace organization, it is useful to "benchmark" our relative success of getting responses to measures of organizational capital with more traditional questions of employer practices. Table 6.5 presents response rates for what we generally consider to be standard production function variables, broken down by manufacturing and nonmanufacturing and then further broken down by firm size, using our 1994 EQW NES survey. As one can see, response rates vary significantly across variables and firm size.

Interestingly, it is the larger establishments that have lower response rates; large nonmanufacturing firms have the lowest response rates across 


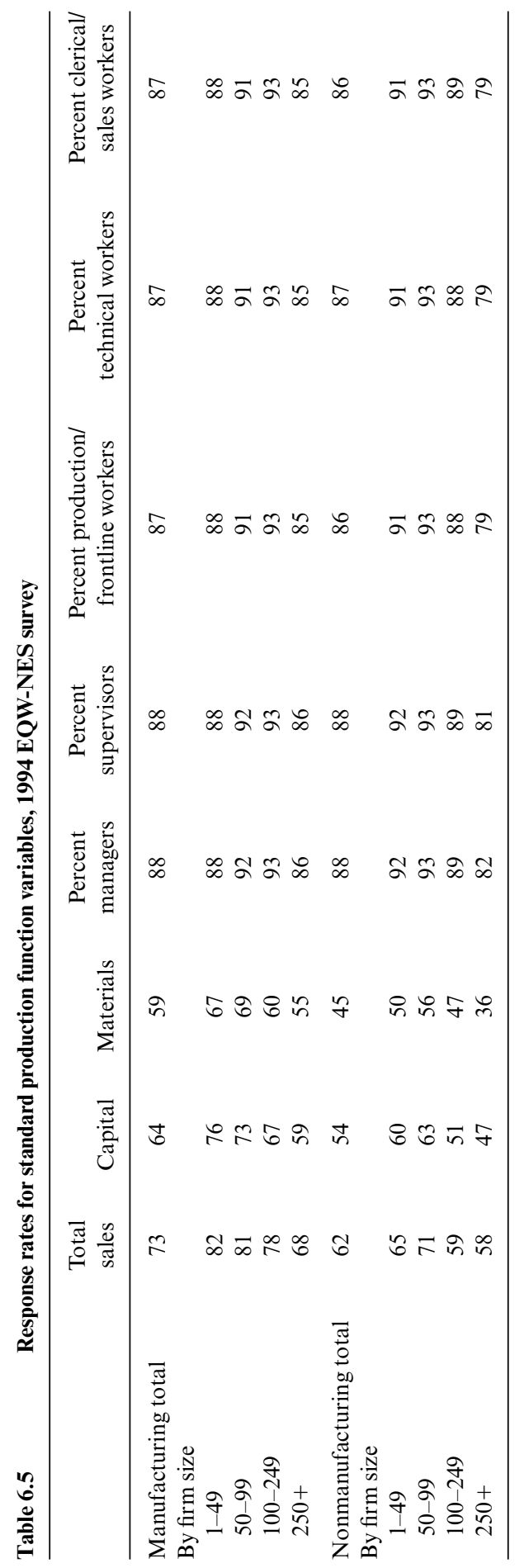


the board. Though this may seem surprising, it may be the case that larger employers are more restricted in terms of the information they are able to release without approval from corporate headquarters. This limitation highlights the importance of allowing for multiple respondents in the survey.

In terms of specific variables, information on materials used generates the highest nonresponse rate, with only 59 percent of manufacturing firms and 45 percent of nonmanufacturing firms responding. Second is capital, with a slightly higher (64 percent manufacturing, 54 percent nonmanufacturing) response rate. Establishments seem most able or willing to respond to questions about employment and the breakdown of the labor force, with response rates in each occupation category of about 87 percent.

These response rates provide a benchmark with which one can consider response rates for survey questions on organizational capital. Table 6.6 provides evidence on response rates for questions regarding training. The top panel shows response rates for types of training, measuring incidence alone. It is clear that these questions are relatively easy for firms to answer, and these factors have been shown to be important factors in production function estimation (Black and Lynch 1996).

The bottom panel of table 6.6 shows that, when one moves beyond the incidence of training, response rates begin to fall. An important factor to measure is the cost of doing training; however, response rates in column (1) suggest that firms, particularly large firms, are not willing or able to answer these questions. In contrast, it is the larger firms in manufacturing industries who seem best able to answer the number of workers trained by occupation; the smallest firms have very low response rates. Among nonmanufacturing firms, the opposite is true, and response rates drop for the largest firms.

It is clear that, when training is measured along these dimensions, it is more difficult to get information from the establishments. However, it is particularly important to do so in order to build up some measure of the stock of additional human capital being added to the firm (similar to new capital investment). And though these intensity measures are more difficult to obtain than simple incidence measures, response rates to these questions are still higher than those for standard capital and materials measures.

Table 6.7 focuses on another aspect of organizational capital: employee voice. Commonly used measures include the existence of a total quality management (TQM) system, the percentage of production or frontline workers meeting in groups, and whether or not an establishment is unionized. As table 6.7 shows, response rates to all of these questions are relatively high, averaging a bit more than 90 percent. These variables have repeatedly been shown to have important impacts on wages as well as productivity.

Establishments also appear to be able to answer questions about the organization of the workplace. As table 6.8 shows, response rates for questions on the organization of the workplace are high, both in manufacturing and nonmanufacturing, large and small establishments. Again, the 


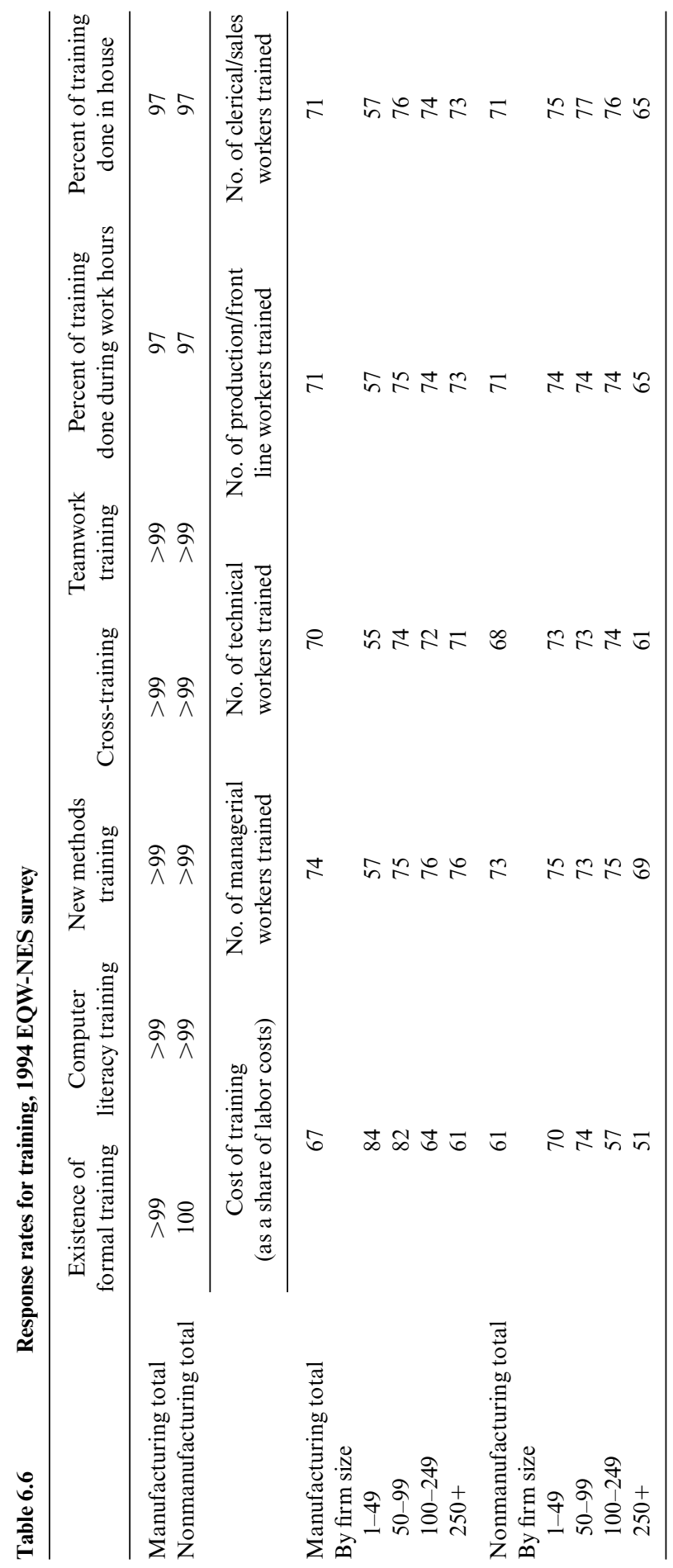


Response rates for employee voice, 1994 EQW-NES survey

\begin{tabular}{|c|c|c|c|}
\hline & $\begin{array}{l}\text { Total Quality } \\
\text { Management }\end{array}$ & $\begin{array}{l}\text { Percentage of production } \\
\text { workers meeting in groups }\end{array}$ & Unionized \\
\hline Manufacturing total & 93 & 90 & 93 \\
\hline \multicolumn{4}{|l|}{ By firm size } \\
\hline $1-49$ & 90 & 89 & 90 \\
\hline $50-99$ & 95 & 94 & 94 \\
\hline $100-249$ & 93 & 92 & 94 \\
\hline $250+$ & 93 & 89 & 93 \\
\hline Nonmanufacturing total & 92 & 87 & 92 \\
\hline \multicolumn{4}{|l|}{ By firm size } \\
\hline $1-49$ & 92 & 91 & 93 \\
\hline $50-99$ & 93 & 92 & 92 \\
\hline $100-249$ & 93 & 90 & 92 \\
\hline $250+$ & 91 & 81 & 90 \\
\hline
\end{tabular}

high response rates are particularly important given that these variables have also been shown to have an impact on productivity and wages in empirical work.

On the compensation side, there is a bit more variation in response rates (see table 6.9). Profit sharing appears to be relatively easy for firms to answer, with response rates hovering around 90 percent in all occupations except technicians, which have slightly lower response rates (particularly in nonmanufacturing and small firms). However, response rates drop significantly when one looks at wages. Again, technicians have the lowest response rates among the occupations. Although response rates seem much lower, it is important to note that they are still significantly higher than those for more commonly collected variables such as capital and materials. As with the more commonly collected variables from table 6.5, response rates fall for larger firms.

Responses to questions, though necessary, are not sufficient. If all firms respond to a question but there is no variation across firms, it is difficult to impossible to identify the impact of that practice on establishment or worker outcomes. Given that we know which questions firms are best willing or able to answer, it is next important to examine how much variation there is in these practices, both across firms and over time. For example, if all firms indicate that they have some informal training in place (incidence), we would not be able to disentangle the effect of informal training on outcome measures.

Tables 6.10 through 6.13 present weighted means for a variety of workplace practices across manufacturing and nonmanufacturing firms by firm size. Table 6.10 shows the incidence of different types of training and then the cost of training, the percentage of training done during work hours, and the percentage of training done in-house. Among types of training, 


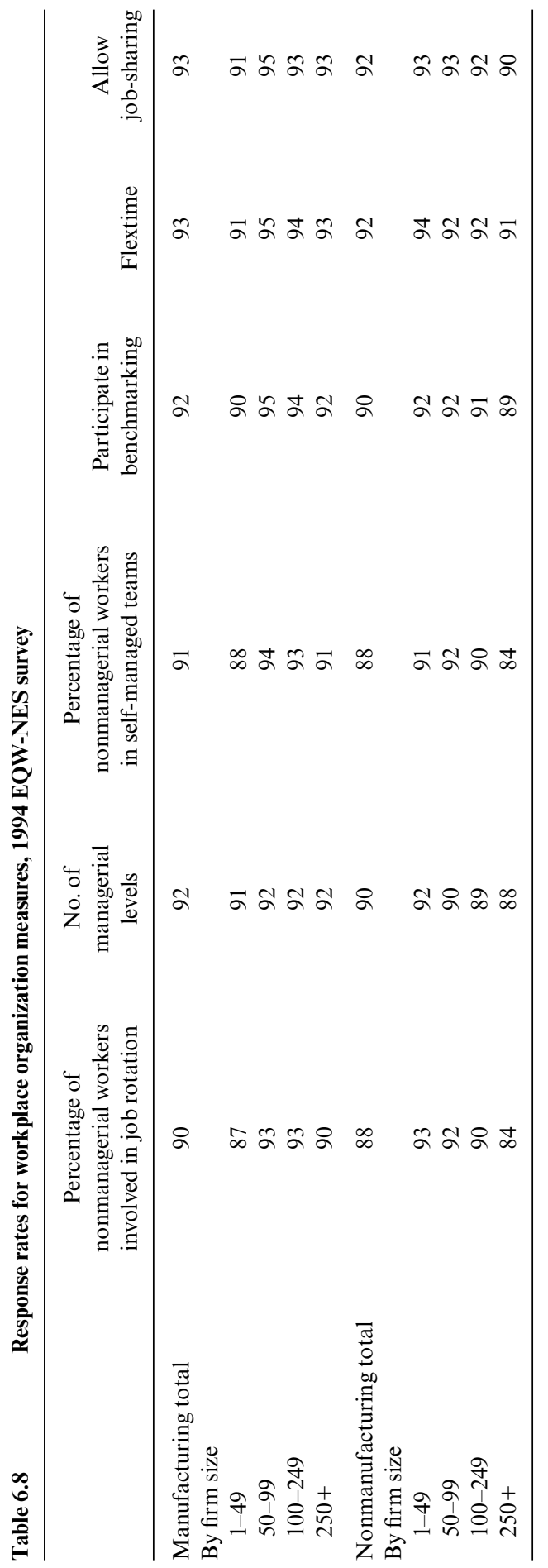




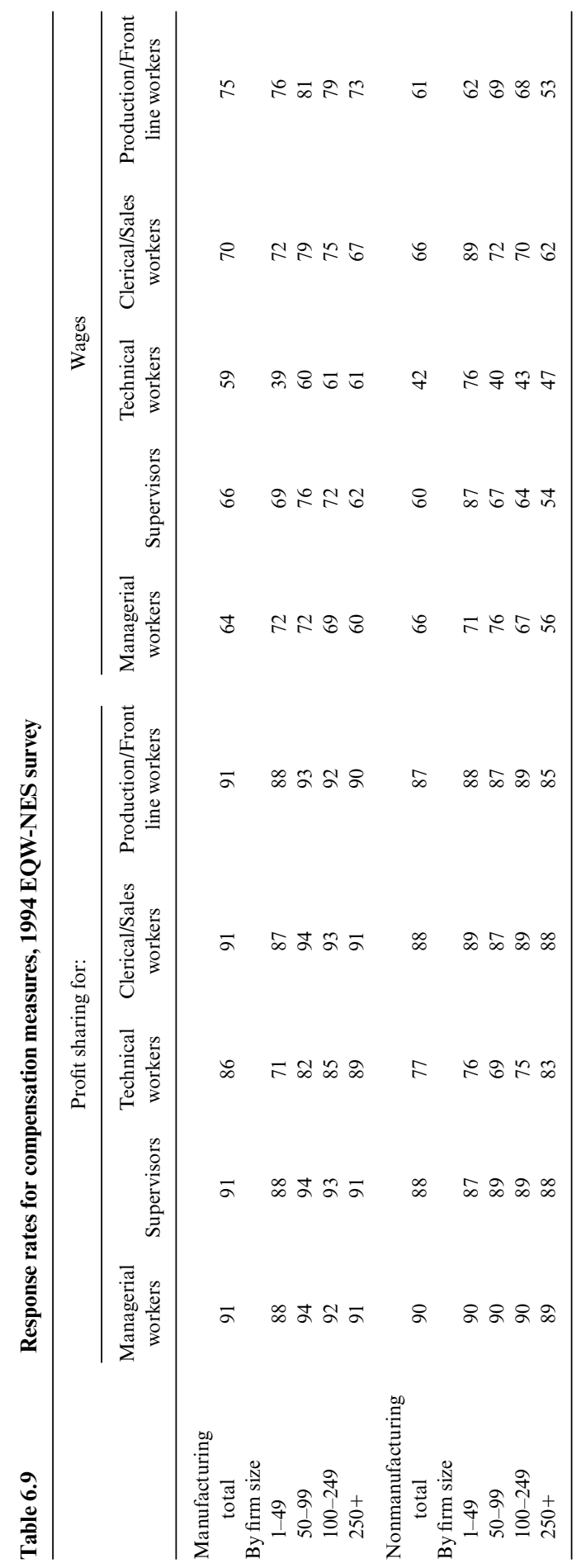




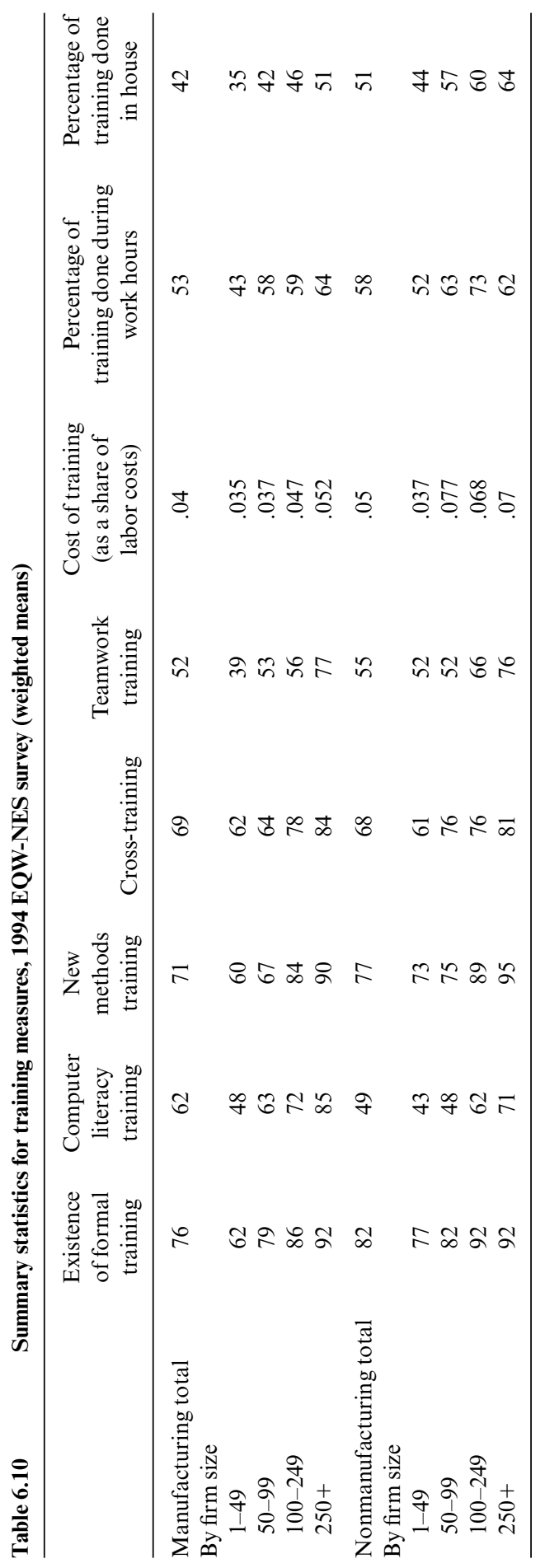


Summary statistics for employee voice measures, 1994 EQW-NES survey (weighted means)

\begin{tabular}{|c|c|c|c|}
\hline & $\begin{array}{l}\text { Total Quality } \\
\text { Management }\end{array}$ & $\begin{array}{l}\text { Percentage of production } \\
\text { workers meeting in groups }\end{array}$ & Unionized \\
\hline Manufacturing total & 42 & 40 & 21 \\
\hline \multicolumn{4}{|l|}{ By firm size } \\
\hline $1-49$ & 28 & 38 & 12 \\
\hline $50-99$ & 41 & 42 & 20 \\
\hline $100-249$ & 52 & 37 & 31 \\
\hline $250+$ & 66 & 50 & 35 \\
\hline Nonmanufacturing total & 36 & 56 & 11 \\
\hline \multicolumn{4}{|l|}{ By firm size } \\
\hline $1-49$ & 33 & 62 & 8 \\
\hline $50-99$ & 36 & 55 & 8 \\
\hline $100-249$ & 38 & 44 & 18 \\
\hline $250+$ & 52 & 41 & 24 \\
\hline
\end{tabular}

smaller firms tend to do less training and there is considerable variation across firm size (see Lynch and Black 1998 for a review). There is also substantial variation across types of training, with fewer firms, on average, providing computer literacy training and more firms providing new methods training. There is also substantial variation across the costs of training. Consistent with the idea that large firms provide more training, training is a higher share of total labor costs for large firms, and there is substantial variation both across firm size and between manufacturing and nonmanufacturing firms. Finally, there is substantial variation in the timing and location of training, with small firms more likely to outsource and provide training outside of work hours. These variables have also been shown to have an association with establishment productivity (see Black and Lynch 1996).

Table 6.11 shows that there is even more variation, relatively speaking, when one looks at employee voice. Among manufacturing establishments, small establishments show much less employee voice: they are less likely to have a system of TQM, a lower percentage of production workers meet in groups, on average, and they are less likely to be unionized. These numbers gradually increase as establishment size grows. In nonmanufacturing, the situation is somewhat different. While many establishments have implemented a TQM system, the smaller establishments are the ones that are most likely to have a larger share of nonmanagerial workers meeting in groups. Although unionization numbers are low across the board in nonmanufacturing, it is not surprising that larger firms are much more likely to be unionized.

Among different measures of the organization of the workplace in table 6.12 , there is far less variation in incidence and diffusion by establishment 


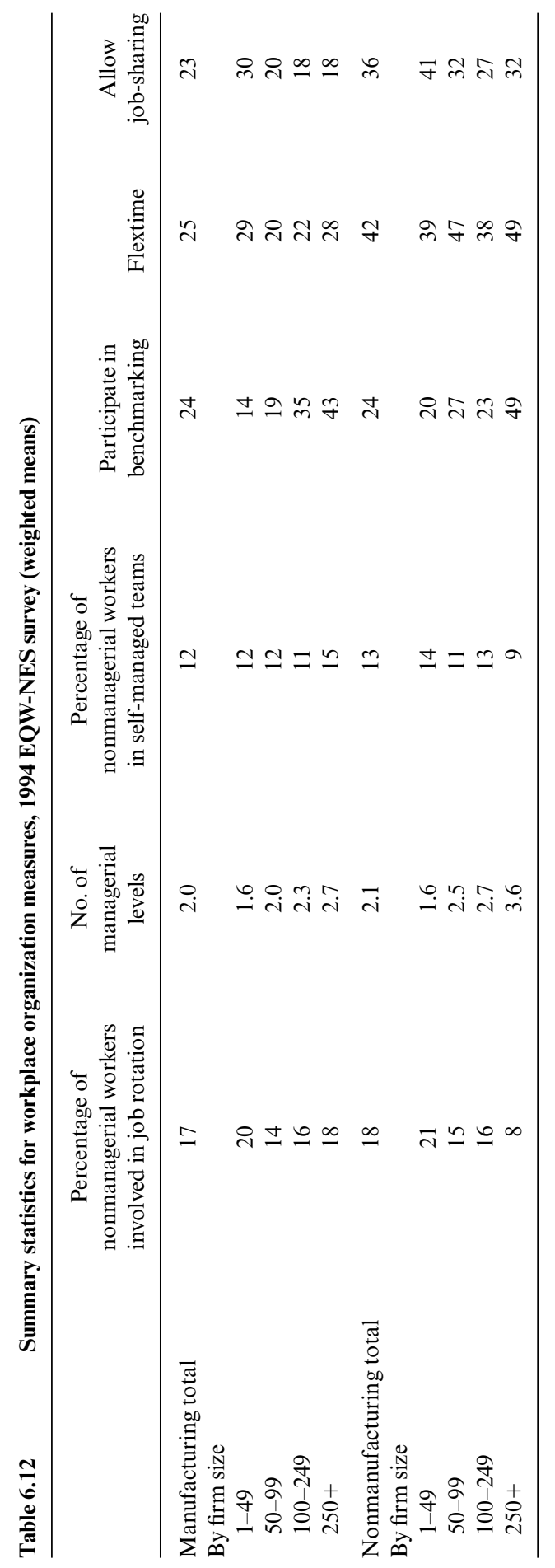


Summary statistics for compensation measures, 1994 EQW-NES survey (weighted means)

\begin{tabular}{lcccc}
\hline & \multicolumn{4}{c}{ Profit sharing for: } \\
\cline { 2 - 5 } & $\begin{array}{c}\text { Managerial } \\
\text { workers }\end{array}$ & $\begin{array}{c}\text { Technical } \\
\text { workers }\end{array}$ & $\begin{array}{c}\text { Clerical/Sales } \\
\text { workers }\end{array}$ & $\begin{array}{c}\text { Production/Front } \\
\text { line workers }\end{array}$ \\
\hline $\begin{array}{l}\text { Manufacturing total } \\
\text { By firm size }\end{array}$ & 66 & 49 & 55 & 49 \\
$1-49$ & 61 & 44 & 51 & 52 \\
$50-99$ & 65 & 53 & 56 & 51 \\
$100-249$ & 71 & 48 & 55 & 39 \\
$250+$ & 75 & 58 & 52 & 46 \\
Nonmanufacturing total & 72 & 42 & 46 & 48 \\
By firm size & 72 & 43 & 47 & 39 \\
$1-49$ & 69 & 36 & 41 & 41 \\
$50-99$ & 73 & 41 & 49 & 53 \\
$100-249$ & 77 & 53 & 51 & \\
$250+$ & & & & \\
\hline
\end{tabular}

size. For manufacturing establishments, there is little variation in the percentage of nonmanagerial workers involved in job rotation, with the number centered around 17 percent. The number of managerial levels does increase as the establishment gets bigger, both in manufacturing and nonmanufacturing. Larger establishments are more likely to participate in benchmarking, while smaller establishments are slightly more likely to allow job sharing. There is little relationship between establishment size and the availability of flextime (though nonmanufacturing establishments are more likely to have it as a whole) or the percentage of nonmanagerial workers in self-managed teams.

Finally, as shown in table 6.13, among measures of compensation, the story is the same for both manufacturing and nonmanufacturing establishments. There is little relationship between establishment size and profit sharing for clerical or sales workers or production or front line workers. However, larger establishments are more likely to offer profit sharing for managerial and technical workers.

In addition to differences across types of establishments, there are also differences over time. If one tries to identify the impact of organizational capital by focusing on changes within establishments over time (in order to eliminate unobserved establishment fixed characteristics), it is essential that there be significant variation over time. This suggests that one should consider not only the questions asked but the frequency with which establishments are surveyed. Table 6.14 examines the variation over time in a number of workplace practices when we consider changes between 1994 and 1997 in the matched panel of establishments in the EQW NES. In this 


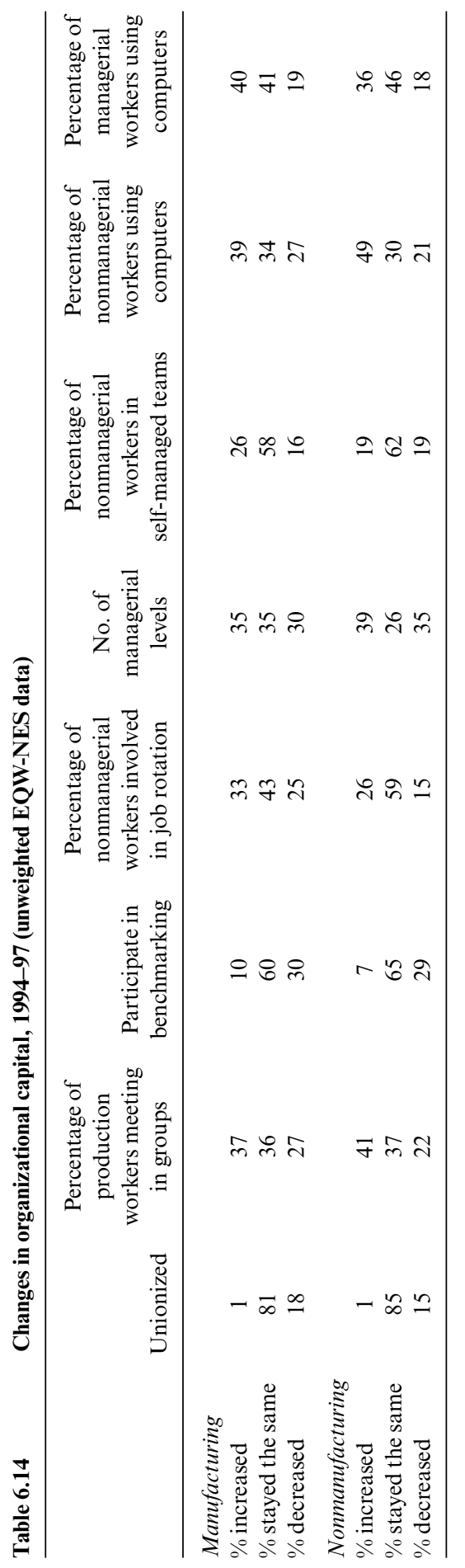


time period, there are a number of similarities across manufacturing and nonmanufacturing establishments. Most establishments did not change their unionization status, with only approximately 15 percent becoming deunionized during this time period and 1 percent unionizing. A significant number of establishments increased the percentage of production workers meeting in groups, while more establishments stopped the process of benchmarking than began. The percentage of nonmanagerial workers involved in job rotation increased, an equal percentage of establishments increased the number of managerial levels as decreased, and there was an unambiguous increase in the diffusion of technology, with more establishments increasing the percentage of managerial and nonmanagerial workers using computers than decreasing.

It is important to note that, when considering changes over time, one is particularly susceptible to issues of measurement error, particularly when focusing on changes over a relatively short period of time. Surveying establishments too frequently exacerbates this problem.

Finally, it is also important to consider the optimal breakdown of worker categories. While many data sets currently distinguish between production and nonproduction workers (for example, the longitudinal research database [LRD]), recent surveys have begun to explore the advantages of finer worker categories. In the EQW NES, workers are divided into supervisors, managers, technical workers, production workers, and clerical workers. While the distinctions may be less important for production function estimation, there may be significant benefits to the finer level of detail when considering the impact of organizational capital on wages and labor demand.

\subsection{Final Recommendations}

This paper has tried to identify three main elements of organizational capital that have been shown to have a significant impact on productivity, wages, and labor demand. These three elements include training, employee voice, and work design. While there have been an increasing number of researchers who have attempted to measure these and other dimensions of organizational capital for the purpose of documenting its impact on the socalled "new economy," these efforts have been uncoordinated and sporadic.

Part of the reason there has been no systematic attempt to measure workplace practices over time has been a lack of consensus on what to measure, along with concerns over the costs of measurement.

Our experience with training measures suggests that, while measuring the capital stock is tough, measuring the stock of training is even tougher. Evidence suggests that it may be too hard for firms to calculate a stock measure, and our best shot is to try to get at new investment in training. But we are still left with questions such as these: what is the appropriate 
margin - any training, type of training, duration of training? How do we think about depreciation?

The good news is that other measures of organizational practices, such as the percentage of workers meeting on a regular basis, unionization, and various work design elements, are much easier to obtain. Respondents have a clear idea of what is being asked, these types of questions are not time consuming, there is currently substantial variation in the data, and, importantly, they are associated with outcomes we care about.

Our final question deals with the frequency of measurement: how often should you measure these elements of organizational capital? Our work suggests that this does not need to be done on a monthly basis or even a quarterly basis. For training and compensation information to be used for labor productivity analysis, an annual survey is probably sufficient. For the other components of organizational capital such as employee voice and work design, checking in every other year is likely more than enough, as these practices do not change with high frequency.

To date, the literature has been clear: workplace organization matters. While these findings have been consistent, the measures of organizational capital, the unit of measurement, and the frequency of measurement have not been. Hopefully, careful consideration of the issues and problems associated with the measurement of organizational capital will help unify data collection efforts in the future, leaving us with more systematic information on firms, including measures not only of physical capital and human capital but also of organizational capital as well.

\section{References}

Acemoglu, Daron. 2000. Technological change, inequality, and the labor market. NBER Working Paper no. 7800. Cambridge, MA: National Bureau of Economic Research, July.

Aghion, Phillipe, Eve Caroli, and Carlos Garcia-Peñalosa. 1999. Inequality and economic growth: The perspective of the new growth theories. Journal of Economic Literature 37 (3): 1615-60.

Atkeson, Andrew, and Patrick J. Kehoe. 2002. Measuring organization capital. NBER Working Paper no. 8722. Cambridge, MA: National Bureau of Economic Research, January.

Arthur, Jeffrey. 1994. Effects of human resource systems on manufacturing performance and turnover. Academy of Management Journal 37:670-87.

Athey, Susan, and Scott Stern. 1998. An empirical framework for testing theories about complementarity in organizational design. NBER Working Paper no. 6600. Cambridge, MA: National Bureau of Economic Research.

Bailey, Thomas. 1993. Organizational innovation in the apparel industry. Industrial Relations 32:30-48.

Bailey, Thomas, Peter Berg, and Carola Sandy. 2001. The effect of high perfor- 
mance work practices on employee earnings in the steel, apparel, and medical electronics and imaging industries. Industrial and Labor Relations Review 54 (2): 525-45.

Barron, J., M. Berger, and D. Black. 1997. How well do we measure training? Journal of Labor Economics 13 (2): 308-33.

1999. The use of matched employee-employer data as a means of assessing data reliability with non-classical measurement error. In The creation and analysis of linked employer-employee data, ed. J. Haltiwanger, J. Lane, J. Spletzer, J. Theeuwes, and K. Troske, 419-38. New York: North Holland.

Bartel, Ann. 1989. Formal employee training programs and their impact on labor productivity: Evidence from a human resource survey. NBER Working Paper no. 3026. Cambridge, MA: National Bureau of Economic Research.

2004. Human resource management and organizational performance: Evidence from retail banking. Industrial and Labor Relations Review

Batt, Rose. 2001. Explaining wage inequality in telecommunications services: Customer segmentation, human resource practices, and union decline. Industrial and Labor Relations Review 54 (2): 425-49.

Blair, Margaret M., and Steven M. H. Wallman. 2001. Unseen wealth: Report of the Brookings Task Force on Intangibles. Washington, DC: Brookings Institution Press.

Black, Sandra, and Lisa M. Lynch. 1996. Human capital investments and productivity. American Economic Review 86 (2): 263-67.

2001. How to compete: The impact of workplace practices and information technology on productivity. Review of Economics and Statistics 83 (3): 434-45.

2004. What's driving the new economy: The benefits of workplace innovation. The Economic Journal 114 (February): F97-F116.

Black, Sandra E., Lisa M. Lynch, and Anya Krivelyova. 2004. How workers fare when employers innovate. Industrial Relations 43 (1): 44-66.

Boning, Brent, Casey Ichniowski, and Kathryn Shaw. 2001. Opportunity counts: Teams and the effectiveness of production incentives. NBER Working Paper no. 8306. Cambridge, MA: National Bureau of Economic Research, May.

Bresnahan, Timothy F., Erik Brynjolfsson, and Lorin M. Hitt. 2002. Information technology, workplace organization, and the demand for skilled labor: Firmlevel evidence. The Quarterly Journal of Economics 117 (February): 339-76.

Cappelli, Peter, and William Carter. 2000. Computer, work organization, and wage outcomes. NBER Working Paper no. 7987. Cambridge, MA: National Bureau of Economic Research, October.

Cappelli, Peter, and David Neumark. 2001. Do "high-performance" work practices improve establishment-level outcomes? Industrial and Labor Relations Review 54 (4): 737-75.

Caroli, Eve, and John Van Reenen. 2001. Skill-biased organizational change? Evidence from a panel of British and French establishments. The Quarterly Journal of Economics 116:1449-92.

Delany, John, and Mark Huselid. 1996. The impact of human resource management practices on perceptions of performance in for-profit and nonprofit organizations. Academy of Management Journal 39:949-69.

Dunlop, John, and David Weil. 1996. Diffusion and performance of modular production in the U.S. apparel industry. Industrial Relations 35 (July): 334-54.

Gittleman, Maury, Michael Horrigan, and Mary Joyce. 1998. Flexible workplace practices: Evidence from a nationally representative survey. Industrial and Labor Relations Review 52 (1): 99-115.

Haltiwanger, John, and Steven Davis. 1991. Wage dispersion between and within 
U.S. manufacturing plants, 1963-1986. Brookings Papers on Economic Activity, Microeconomics: 115-200.

Hunter, Larry W., Annette Bernhardt, Katherine L. Hughes, and Eva Skuratowicz. 2001. It's not just the ATMs: Technology, firm strategies, jobs, and earnings in retail banking. Industrial and Labor Relations Review 54 (2): 402-24.

Huselid, Mark A. 1995. The impact of human resource management practices on turnover, productivity, and corporate financial performance. Academy of Management Journal 38 (3): 635-72.

Huselid, Mark A., and Brian E. Becker. 1996. High performance work systems and firm performance: Cross-sectional versus panel results. Industrial Relations 35: 400-22.

Ichniowski, Casey. 1990. Human resource management systems and the performance of U.S. manufacturing businesses. NBER Working Paper no. 3449. Cambridge, MA: National Bureau of Economic Research, September.

Ichniowski, Casey, and Kathryn Shaw. 2003. Beyond incentive pay: Insiders' estimates of the value of complementary human resource management practices. The Journal of Economic Perspectives 17 (1): 155-78.

Ichniowski, Casey, Kathryn Shaw, and Gabrielle Prennushi. 1997. The effects of human resource management practices on productivity. American Economic Review 87 (3): 291-313.

Kandel, E., and Edward Lazear. 1992. Peer pressure and partnerships. Journal of Political Economy 100:801-17.

Kelley, Maryellen. 1994. Information technology and productivity: The elusive connection. Management Science 40:1406-25.

- 1996. Participative bureaucracy and productivity in the machined products sector. Industrial Relations 35:374-99.

Kremer, Michael, and Eric Maskin. 1996. Wage inequality and segregation by skill. NBER Working Paper no. 5718. Cambridge, MA: National Bureau of Economic Research, August.

Kruse, Douglas, and Joseph Blasi. 1998. The new employee/employer relationship. Rutgers University, Aspen Institute Domestic Strategy group. Mimeograph, August.

Lynch, Lisa M., and Sandra E. Black. 1998. Beyond the incidence of training: Evidence from a national employers' survey. Industrial and Labor Relations Review 52 (1): 64-81.

Malcomson, James. 1983. Trade unions and economic efficiency. The Economic Journal 93:50-65.

Milgrom, P., and J. Roberts. 1995. Complementarities and fit: Strategy, structure, and organizational change in manufacturing. Journal of Accounting and Economics 19:179-208.

Osterman, Paul. 1994. How common is workplace transformation and who adopts it? Industrial and Labor Relations Review 47 (2): 173-87.

2000. Work reorganization in an era of restructuring: Trends in diffusion and effects on employee welfare. Industrial and Labor Relations Review 53 (2): 179-96. 


\section{Comment Kathryn Shaw}

There is no doubt that organizational capital contributes to the value of some firms. The human resource practices - such as teams, training, and work design - that form organizational capital have been shown to raise productivity and to raise stock market value. Moreover, the case study evidence illuminating the value of human resource practices is persuasive. Therefore, it is time that we seek to quantify and understand how organizational capital raises productivity or market value for firms in the future. In all likelihood, firms' investments in physical capital are declining and their investments in organizational capital are rising. If we don't measure these intangible investments, we will not be able to explain or predict economic growth.

Therefore, Black and Lynch examine the potential ways in which we might measure organizational capital. They emphasize several criteria to be used in developing the measures of organizational practices: first, we want to develop survey questions that have a reasonable response rate, so the data are fairly complete; second, we want variables that the survey respondents understand and can readily answer; and third, we want variables that have some variance across firms so there is real information in the data. The authors focus on the use of the EQW data to assess each of these requirements for the extensive variables that were developed for that survey. In addition, we also want to measure variables, such as teamwork, that have been shown to have an impact on performance, so the authors review the human resource (HR) productivity or HR performance literature. These are all excellent points.

As for extending their analysis in the future, I have several suggestions.

1. One goal in measuring organizational capital is to add organizational variables to standard surveys, such as census surveys, so that we can really develop a time series on these investments. In this case, we must isolate a few key variables that might serve as proxies for a longer list of variables. Using the Black and Lynch definition of organizational capital, we would wish to find key measures for the three categories of teamwork, training, and job design (and I would add forms of incentive pay). Black and Lynch give us some guidelines for uncovering such variables. In addition to their suggestions, we should do two further things. First, we would want to ask if there are HR practices that serve as the key variables in systems of complementary HR practices. For example, some firms may have "teambased" systems, with all other HR practices aimed at supporting the teams.

Kathryn Shaw is the Ernest C. Arbuckle Professor of Economics in the Graduate School of Business, Stanford University, and a research associate of the National Bureau of Economic Research. 
It is likely that systems of HR practices vary across industries, technologies, and firms, but we should examine the data and literature with this question of identifying HR systems in mind. Second, we want to look at a correlation matrix of the HR practices, or undertake factor analysis, to isolate those key HR measures. We could do this by industry or by firm size.

2. What are firms doing differently when they invest in new organizational practices - how does their production process change? In addition to measuring the practices, we might measure the changes that they produce. For example, in work on the impact of HR practices on performance, we create a variable called "connective capital" (Ichniowski and Shaw 2004). Connective capital is the amount of communication links within the work area, where high communications tend to represent greater amounts of local problem solving by workers (rather than by engineers or managers). Connective capital is correlated with innovative HR practices, such as teamwork, incentive pay, information sharing, extensive training, and careful hiring.

3. We should look to the literature to see if some HR practices seem to raise the level of output when they are adopted, and if other practices continually raise the growth rate of output. Both matter to our models of economic growth, but in different ways.

4. Finally, although good measures of organizational practices may predict economic growth, we also want to know which types of firms will gain the most from these practices. Knowledge regarding which firms invest will help us make policy statements, both on the likely growth of potential output and also on possible ways of subsidizing these investments (such as training) if such subsidies are warranted because there are externalities with organizational investments that firms can't internalize. For example, if organizational investments require a workforce with high levels of general skills, then we should examine options for government subsidies for these skills, like forms of education. We have very little empirical knowledge of the adoption of practices, and yet clearly this knowledge of adoption practices is essential and may be facilitated by these more extensive data on organizational practices.

Overall, Black and Lynch suggest important ways of measuring organizational capital, and in the long run, measures of organizational capital could be very important in both predicting and creating economic growth.

\section{References}

Ichniowski, Casey, and Kathryn Shaw. 2004. Connective capital: Building problemsolving networks within firms. Stanford University, Graduate School of Business. Working Paper, January. 